Ukrainian Journal of Nephrology and Dialysis
Scientific and Practical, Medical Journal

\section{Nephrology School}

doi: $10.31450 /$ ukrjnd.4(68).2020.11

\author{
O.V. Syniachenko ${ }^{1}$, M.O. Kolesnyk ${ }^{2}$, N.M. Stepanova ${ }^{2}$, \\ M.V. Iermolaieva ${ }^{1}$
}

\title{
History of studying the kidney pathology in the mirror of numismatics. Report 1 . Antiquity and middle ages
}

\author{
${ }^{1}$ Donetsk National Medical University, Lyman, Ukraine \\ ${ }^{2} \mathrm{SI}$ «Institute of Nephrology of the NAMS of Ukraine», Kyiv, Ukraine
}

\section{Citation:}

\section{Article history:}

Received May 14, 2020 Received in revised form May 22, 2020 Accepted May 29, 2020
Syniachenko OV, Kolesnyk MO, Stepanova NM, lermolaieva MV. History of studying the kidney pathology in the mirror of numismatics. Report 1. Antiquity and middle ages. Ukr J Nephr Dial. 2020;4(68):74-80. doi: 10.31450/ukrjnd.4(68).2020.11

\begin{abstract}
The branch of historical science of numismatics (from the Latin «numisma» - coin) originated in the 19th century and became closely connected with economics, politics, culture and law, it includes a thematic study of coins, medals and plaque. Best of all, the history of uronephrology is illustrated by various forms of medalist educational art (exonum or paranumismatics), and the medal became the prototype of the memorial coin. This work presents a catalog of more than 400 numismatic materials (including some unique, first cited), reflects the stages of development of the study of the structure and function of the kidneys, methods for diagnosing and treating diseases, there are links to significant historical events, brief biographies of physicians who have made an invaluable contribution are mentioned into the formation of this scientific discipline. The work presents a role in the origin of the study of kidney and urinary tract diseases of ancient physicians (Aretea, Aristotle, Galen, Hippocrates, Rufus, Sushruta, Empedocles) and doctors of the Middle Ages (Avicenna, Da Carpi, Panaskerteli, Paracelsus, Sun Simiao).
\end{abstract}

Key words: medicine, nephrology, urology, history, numismatics.

Conflict of interest statement. The authors declare no competing interest.

(C) Syniachenko O.V., Kolesnyk M.O., Stepanova N.M., Iermolaieva M.V., 2020. All rights reserved. 
(с) Синяченко О. В., Колесник М. О., Степанова Н. М., Ермолаєва М. В., 2020

УДК: 616.613-036.11-085+737:61.09

\section{О.В. Синяченко ${ }^{1}$, М.О. Колесник ${ }^{2}$, Н.М. Степанова ${ }^{2}$, М.В. Срмолаєва ${ }^{1}$ \\ Історія вивчення патології нирок у дзеркалі нумізматики. Повідомлення 1. Античність та середньовіччя}

1 Донецький національний медичний університет МОЗ України, м. Лиман, Україна ${ }^{2} Д У$ «нститут нефрології НАМН України», Київ, Україна

Резюме. Галузь історичної науки нумізматика (від латинського «питіsта» - монета) зародилася в XIX столітті і стала тісно пов'язаної з економікою, політикою, культурою й правом, включає в себе тематичне вивчення монет, медалей та плакет. Найкраще історію уронефрології ілюструють різні форми медальерного образотворчого мистецтва (екзонумія або паранумізматика), а медаль стала прообразом пам'ятної (меморіальної) монети. У даній роботі подано католог понад 400 нумізматичних матеріалів (в тому числі деяких унікальних, вперше наведених), відображено етапи розвитку вивчення будови і функції нирок, методів діагностики й лікування хвороб, є посилання на значні історичні події, згадуються короткі біографії медиків, які зробили неоціненний внесок у формування цієї наукової дисципліни. В роботі представлено роль у зароджсенні вивчення хвороб нирок й сечовивідних шляхів медиків Античності (Аретея, Аристотеля, Галена, Гіппократа, Руфуса, Сушрути, Емпедокла) і лікарів Середньовіччя (Авіценни, Да Карпі, Панаскертелі, Парацельса, Сунь Си-мяо).

Ключові слова: медицина, нефрологія, урологія, історія, нумізматика.

Вступ. Спочатку визначимося $з$ дефініцією «нумізматики». Це слово походить від латинського «нумізма» (монета), яке означає «звичай, що встановився, громадський порядок, традиція, правова норма». У зв'язку з цим «монета» (одиниця вартості, металевий грошовий знак) стало похідним поняття «повної міри, законної норми». Нумізматика, яка зародилася в XIX столітті, є галуззю історичної науки, пов'язаної з економікою, політикою, культурою і правом [1]. До нумізматичних матеріалів належать монети, медалі й плакети (від французького «плакетта» - «Пластинка», «плак» - «тонкий шматочок металу»). Якнайкраще ілюструють історію нефроурології різні форми медальерного образотворчого мистецтва (екзонумія або паранумізматика). Медаль є прообразом пам'ятної (меморіальної) монети. Перший винахід металевої монети із засвідчуючими зображеннями і написами належить у двох сусідніх регіонах Егеїди в Лідійському царстві (685 р. до р.х.) на західному узбережжі Малої Азії та на острові Егіна в Греції (між півостровом Пелопонес і Аттікою). В цей саме час, незалежно від Європи, монети виникли у Китаї. Підкреслимо, що медицину було відображено вже на античних монетах Стародавніх Греції та Риму [2, 3, 4].

Метою даної роботи стала оцінка розвитку світової нефрології й урології, відображеної на нумізматичних матеріалах, за історичний період до

\section{Синяченко Олег Володимирович} synyachenko@ukr.net
Нового часу (тобто епохи Античності та Середньовіччя). Вперше проаналізовано понад 400 монет, медалей та плакет, які за багато років склали певний каталог з коротким описом історичних подій. Умовними позначками стали: [0] - монета, [0] медаль, [•] - медаль з підвіскою, [曰] - плакета.

Нирки людини згадуються ще Біблії як місце темпераменту, емоцій, розсудливості, енергії й мудрості, а також божего покарання за скоєні вчинки [5]. Є відомості про опис нирок в Талмуді, Мідраші, Корані $[6,7]$. Ще майже 800 років до р.х. відомий індійський медик Сушрута \{рис. 1-2\} у своєму творі «Самхіта» надав повну систему давньоіндійської медицини в контексті лікування захворювань нирок і сечовидільних шляхів, для цього навів понад 650 лікарськіх засобів [8]. Давньогрецький лікар, уродженець сицилійського Агрігента Емпедокл (490-430 до р.х.) \{рис. 3-4\} особливу увагу приділяв проблемам анатомії та фізіології нирок, розробив теорію «шпар та витікань», яка слугувала поясненню відчуттів й містила зачатки атомістичних уявлень [9].

В нашій попередній роботі [10] подано 51 нумізматичний матеріал, присвячений грецькому геніальному лікареві, «батькові медицини» Гіппократу ( 460-377 до р.х.), який мешкав на острові Кос, а у своєму «Corpus Hippocraticum» вперше представив ниркову термінологію [11] и основні ознаки захворювань такого профілю $[12,13]$. Ще один уродженець Давньої Греції (Стагірі), вчений-енциклопедіст Арістотель (384-322 до р.х.) \{рис. 5-16\}, який навчався в Афінській академії Платона, описав частковість нирок, заклав основи порівняльної анатомії, його праці мали вплив на подальший розвиток уронефрології, хоча помилково вважав, що випита рідина проходить з пухкої поверхні кишечника безпосередньо в сечовий міхур $[14,15]$. 


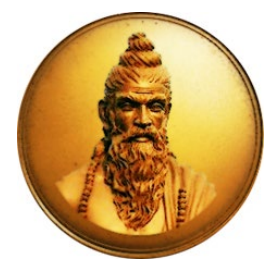

$1[\bullet]$

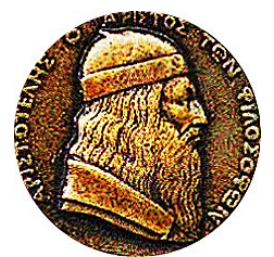

$7[\bullet]$

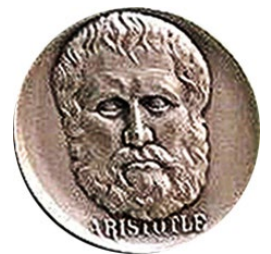

$13[\bullet]$

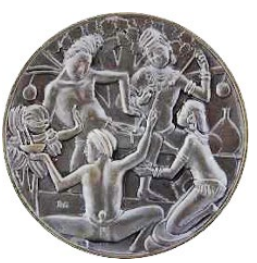

$2[\bullet]]$

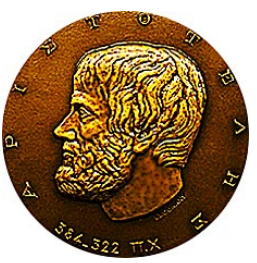

$8[\bullet]]$

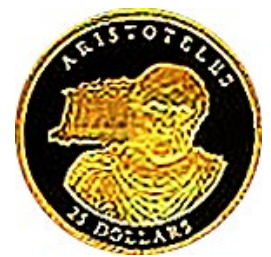

$14[\bullet]]$

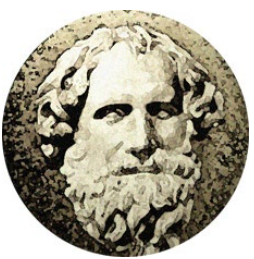

$3[\bullet]$

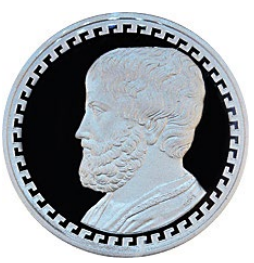

$9[\bullet]$

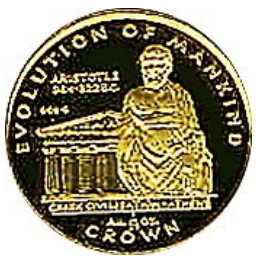

$15[\bullet]$

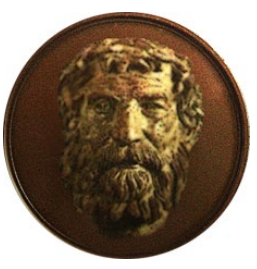

$4[\bullet]$

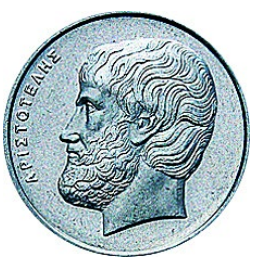

$10[\mathbf{O}]$

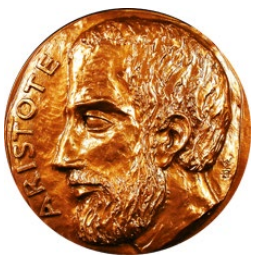

$16[\bullet]$

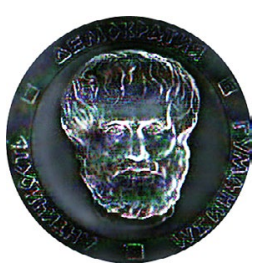

$5[\bullet]$

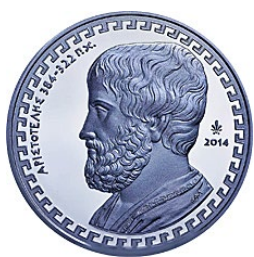

$11[0]$

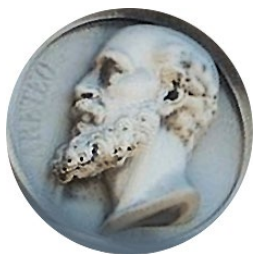

$17[\bullet]$
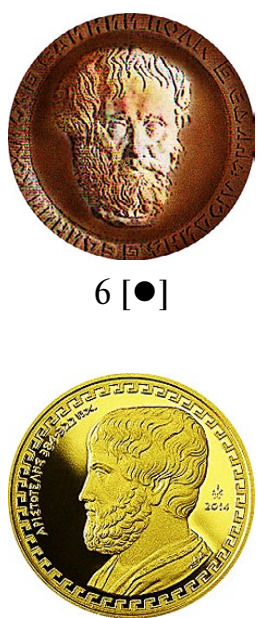

$12[0]$

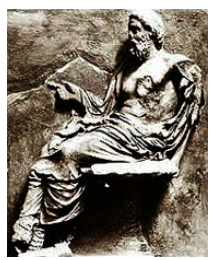

$18[\mathbf{\square}]$

Певний внесок у розвиток античної медицини ранньої Римської імперії зробили Аретей із Каппадокії ( 80-135) \{рис. 17\} та Руфус з Ефеса $(\sim 80-150)$ \{рис. 18$\}$. Перший з них хвороби уронефрологічного профілю почав розподіляти на гострі й хронічні $[16,17]$, а другий загалом вважається фундатором сучасної нефрології [18], оскільки наприкінці I століття був автором піонерської книги «Захворювання нирок та сечового міхура», де підкреслював важливість знань з анатомії і вважав за краще прагматичний підхід до діагностики й лікування хвороб нирок [19].

Лікарі античності враховували такі характеристики сечі, як «хороша», «погана» $\mathrm{i}$ «кривава»,

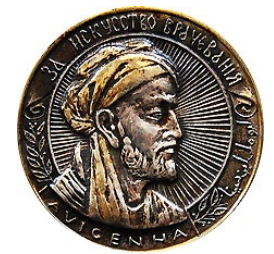

$19[\bullet]$

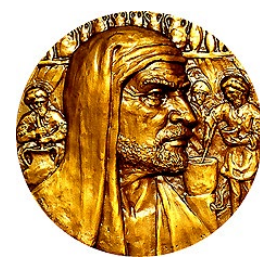

$25[\bullet]$

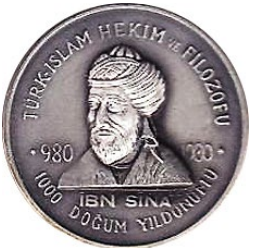

$20[\bullet]]$

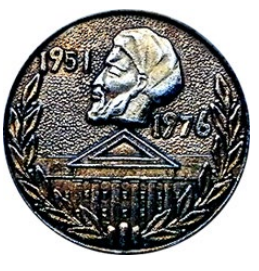

$26[\bullet]]$

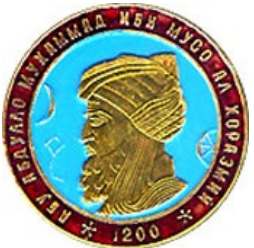

$21[\bullet]$

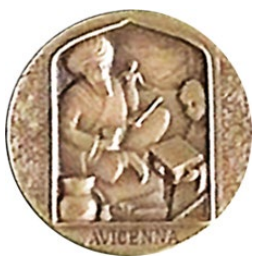

$27[\bullet]$

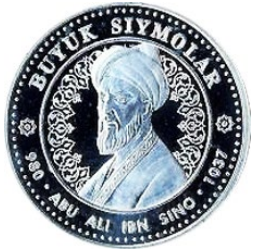

22 [0]

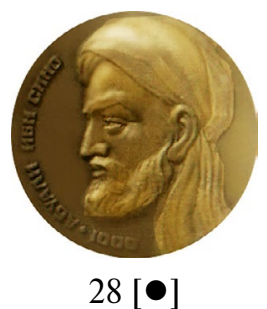

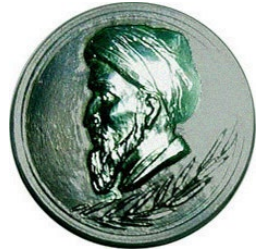

$23[\bullet]$

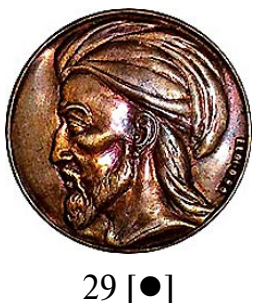

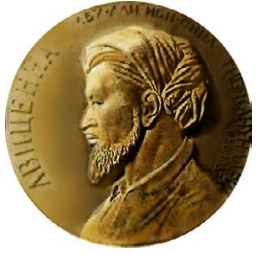

$24[\bullet]$

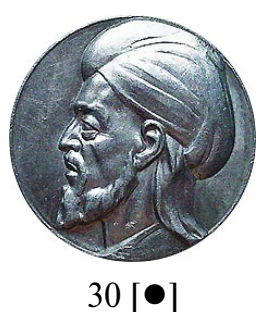




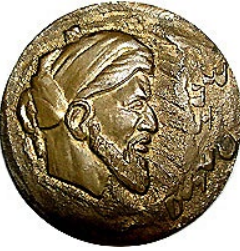

$31[\bullet]$

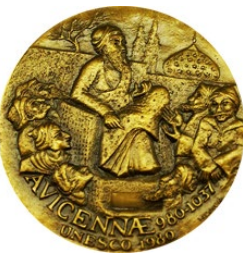

$37[\bullet]$

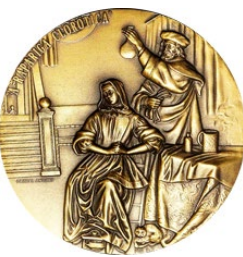

$43[\bullet]$

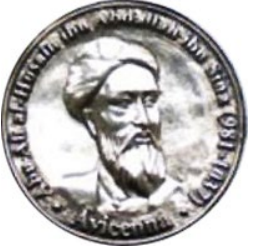

$32[\bullet *]$

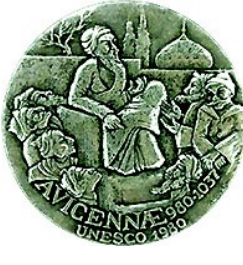

38 [0]]

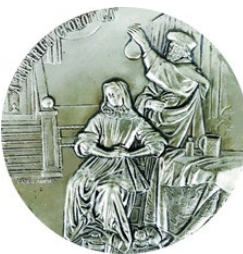

44 [0]]

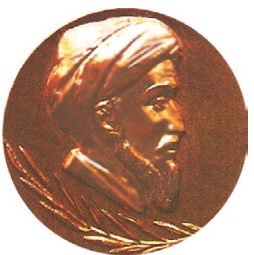

$33[\bullet]$

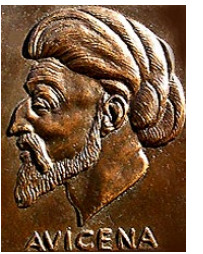

$39[\mathbf{\square}]$

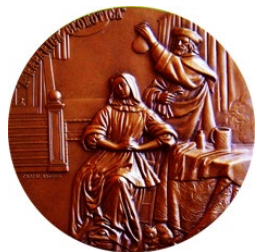

$45[\bullet]$

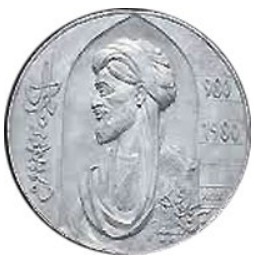

34 [•]

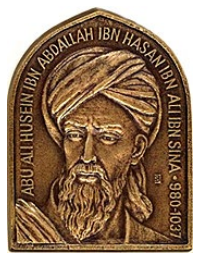

40 []

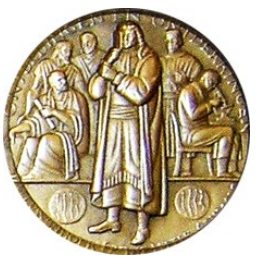

46 []

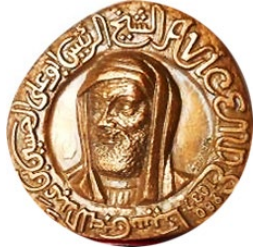

35 []

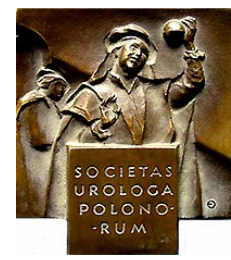

$41[\mathbf{\square}]$

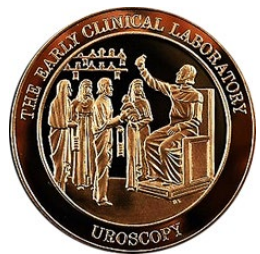

47 [•]
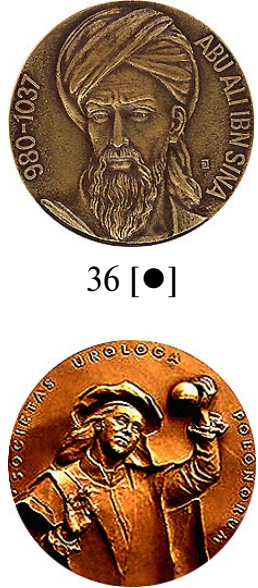

42 []

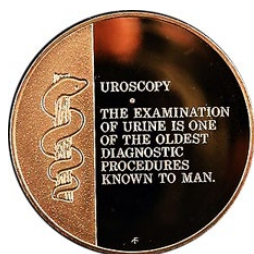

$48[\bullet]$

Давньоримський медик Гален Клавдій ( 129201) \{рис. 49-69\}, що народився у Пергамі (Мала Азія), вивчав анатомію і фізіологію нирок, широко користуючись дослідами над тваринами, а носієм сигналів роздратування сечовиділення вчений вважав психічну пневму, яка передає відчуття до мозку, а далі до нирок. На думку К.Галена в легенях пневма стикається з повітрям, надходить потім в серце і розноситься до нирок $[27,28]$. Знаменитий китайський лікар часів династії Тан уродженець

Хуаяня (сучасна провінція Шеньсі) Сунь Си-мяо (581-682) \{рис. 70-72\} отримав прізвисько «Яо-ван» («цар медицини»), є автором творів з лікування хвороб сечової системи, зокрема «Тисяча золотих лікувальних рецептів» та «Підтримуючі оздоровчі рецепти тисячу золотих». Покровитель аптекарів, згідно китайської міфології, він використовував тридцять священних рецептів, які включив до свого медичного трактату «Цянь цзинь фан і» [29].

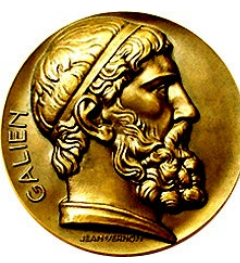

49 []

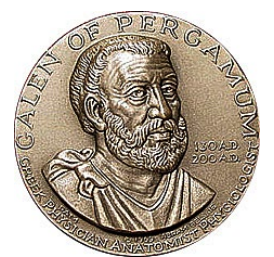

55 [•]

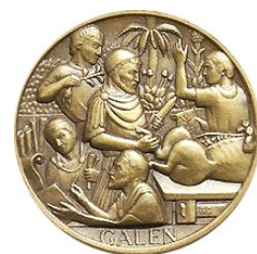

61 [ㅂ]

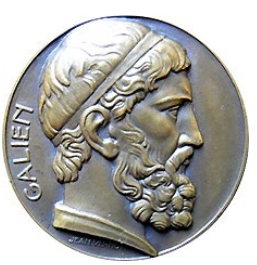

50 [•*]]

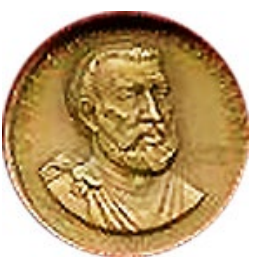

56 [○]]

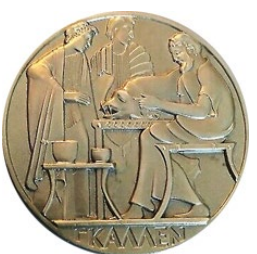

62 [०]]

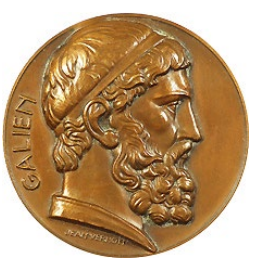

51 [•]

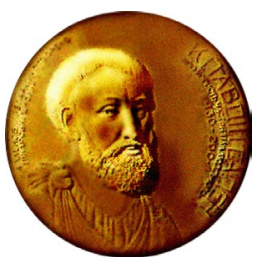

57 [•]

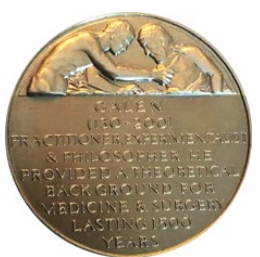

63 [•]

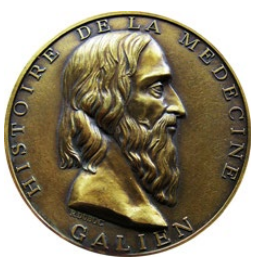

52 [•]

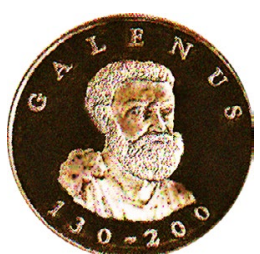

58 []

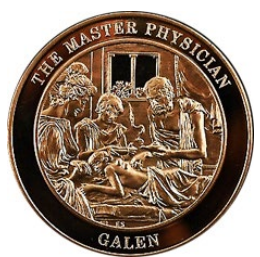

64 []

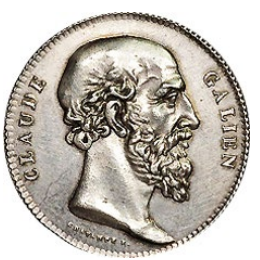

53 []

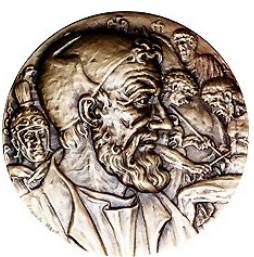

54 []

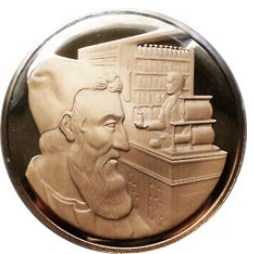

59 [•]

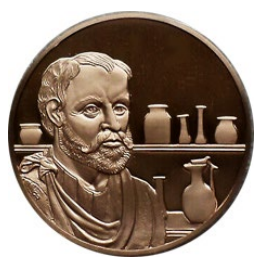

60 []

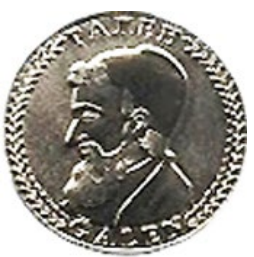

65 [*]

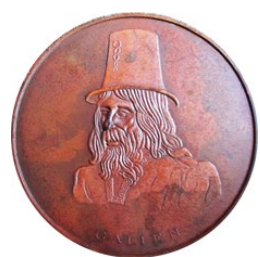

66 [] 


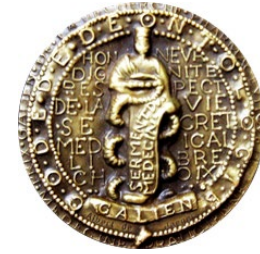

$67[\bullet]$

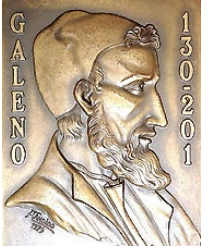

$68[\boldsymbol{\square}]]$

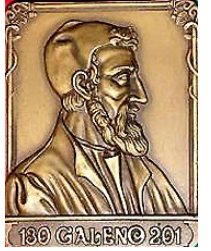

$69[\mathbf{a}]$

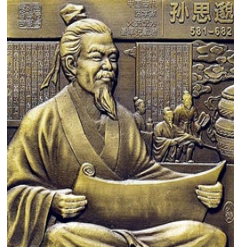

$70[\mathbf{\square}]$

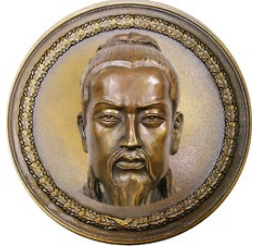

$71[\bullet]$

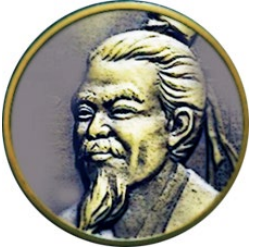

$72[0]$
Уродженець іспанської Кордови, видатний єврейський лікар Маймонід Мойсей бен-Маймонд (Рамбам) (1135/38-1204) \{рис. 73-82\} вперше вказав на зміни нирок при хворобах серця, а всі захворювання сечовиділення пропонував лікувати соком редьки [30, 31]. Знаменитий лікар швейцарсько-німецького походження епохи Відродження, уродже- нець Ейнзільдена (кантон Швіц), засновник ятрохімії Парацельс (Філіп Ауреол Теофраст Бомбаст фон Гогенгейм) (1493-1541) \{рис. 83-117\} для хвороб нирок виділяв ліки з рослин і застосовував їх у вигляді тінктур, екстрактів та еліксирів, розвивав нове для того часу уявлення про їх дозування, використовував мінеральні природні джерела [32].

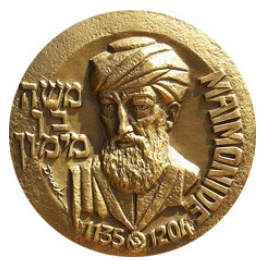

$73[\bullet]$

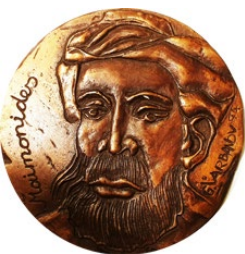

$78[\bullet]$

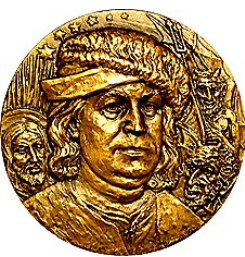

84 []

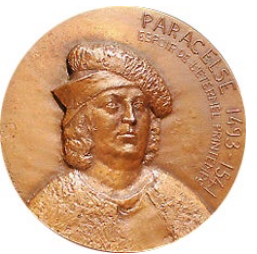

90 [ㅇ]

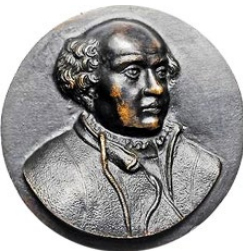

96 [ㅂ]

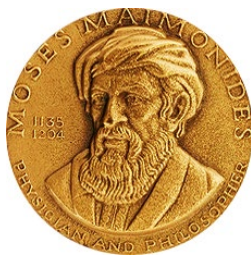

74 []]

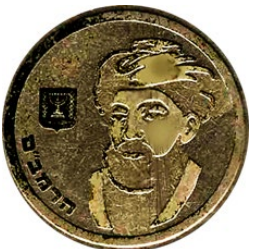

79 [0]]

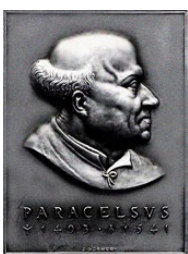

$85[\boldsymbol{\square}]]$

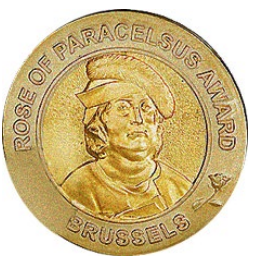

91 [이]

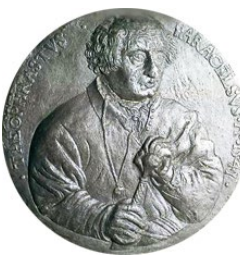

97 []]

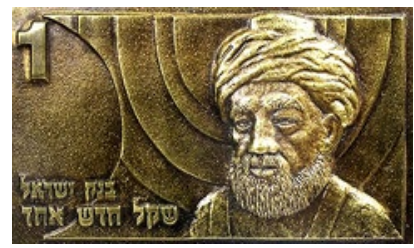

$75[\mathbf{\square}]$

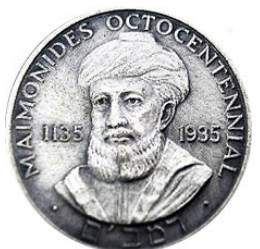

80 []

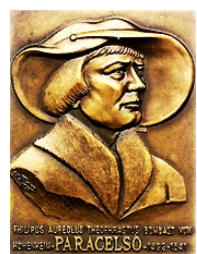

86 []

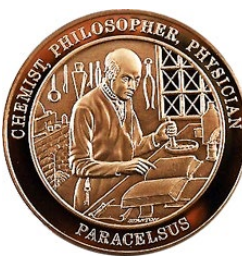

92 [•]

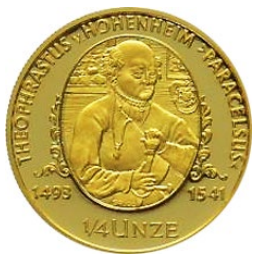

98 [ㅂ]

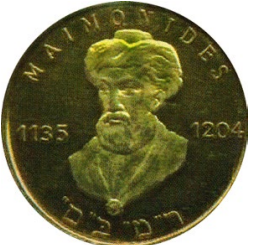

81 [ㅇ]

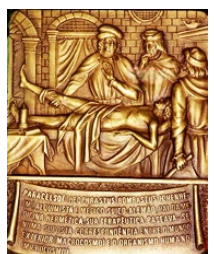

87 []

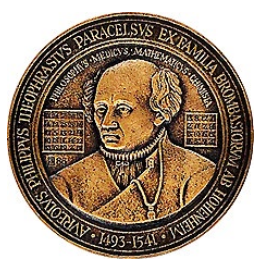

93 [•]

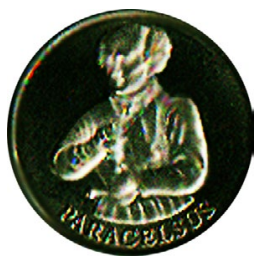

99 [०*]

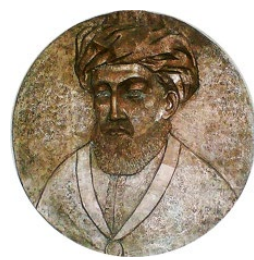

$76[\bullet]$

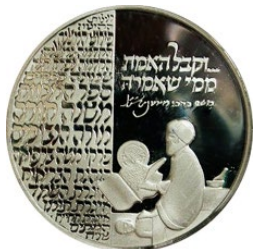

82 [ㅂ]

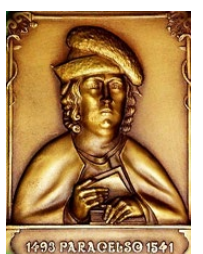

88 [ᄆ]
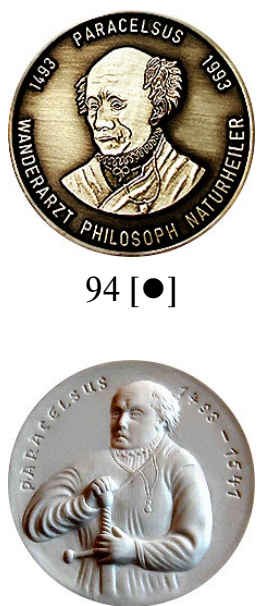

100 []
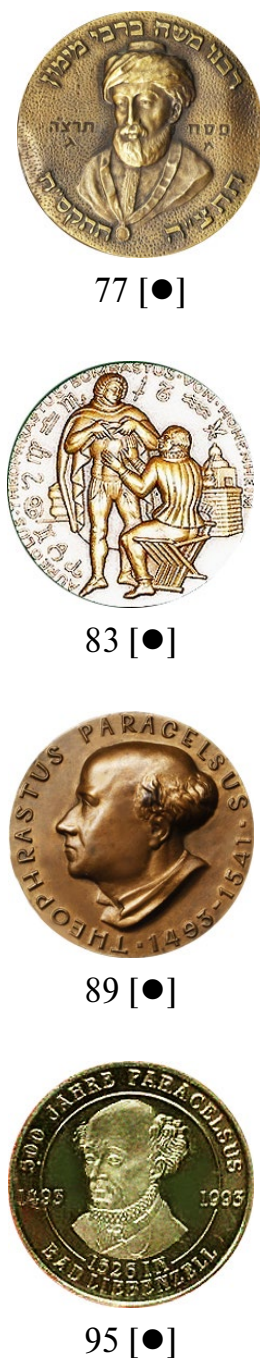

77 [@]

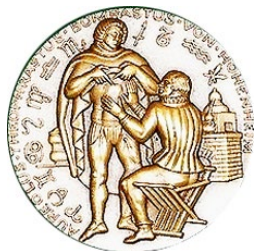

83 [이

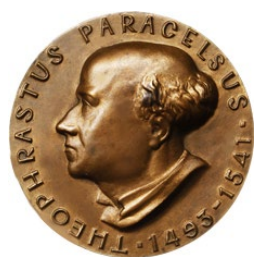

89 [이

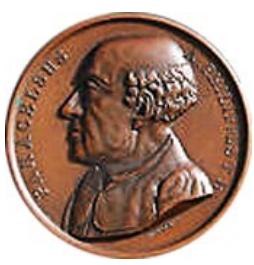

101 [] 


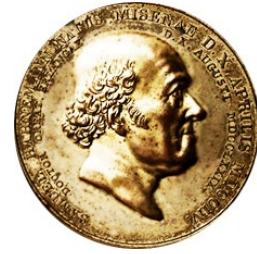

102 [ㅇ]

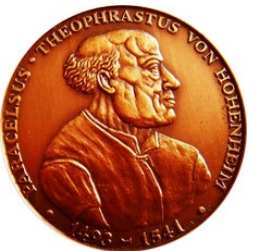

$108[\bullet$

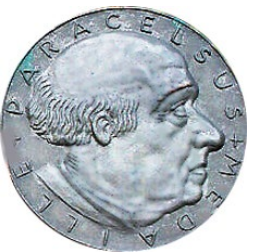

$114[0]$

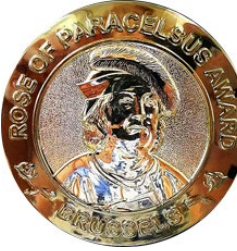

$103[0]]$

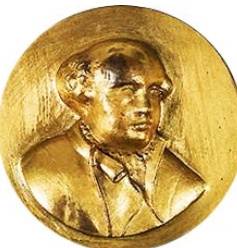

$109[\mathbf{\square}]]$

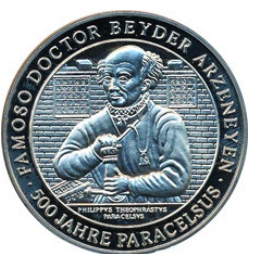

115 [ם]]

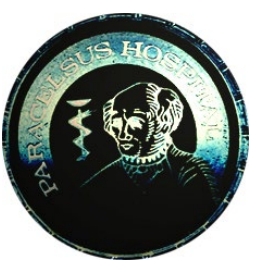

$104[\circ]$

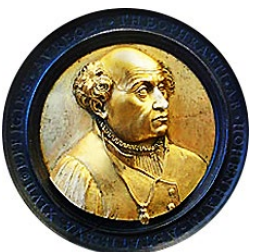

$110[0$

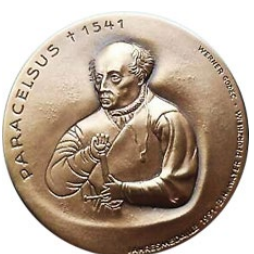

$116[\square$

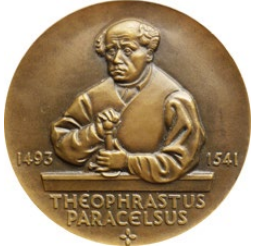

$105[\bullet$

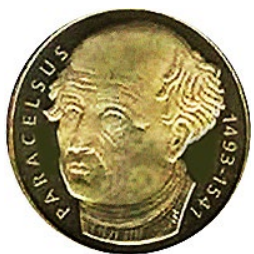

$111[\mathbf{O}]$

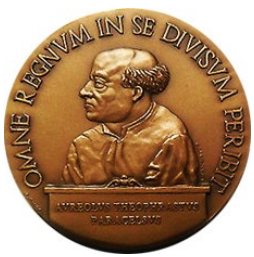

$117[\mathbf{\square}]$

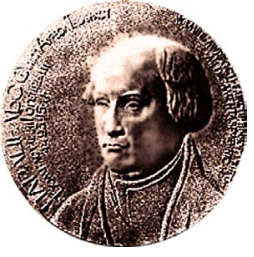

$106[\bullet]$

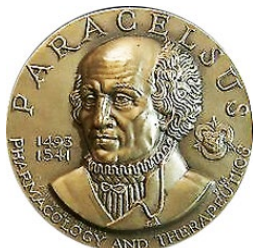

$112[\bullet]$

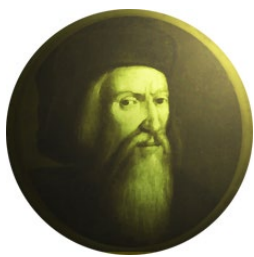

$118[\bullet]$

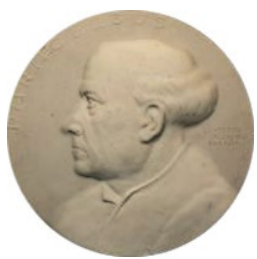

$107[\bullet]$

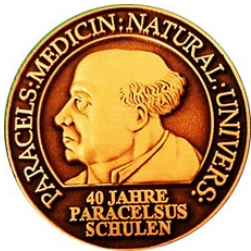

$113[\bullet]$

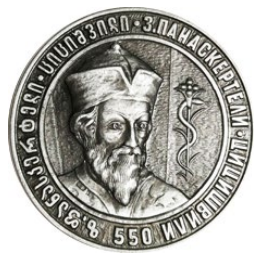

$119[\bullet]$

В один час з Парацельсом наприкінці епохи Середньовіччя мешкали італійський анатом, випускник університету Болоньї Да Карпі Якопо Беренгаріо (1460-1530) \{рис. 118\} та грузинський лікар Панаскертелі-Цицишвілі Заза (1425-1501) \{рис. 119\}. Я.Б.Да Карпи зробив кілька важливих наукових досягнень, в тому числі створив перший анатомічний текст сечової системи з ілюстраціями «Anatomia Carpi. Isagoge perlucide ac uberime. Anatomiam humani corporis», де підкреслював сенсорне сприйняття текстових версій істини і був зроблений акцент на розтині трупів людини, подано деякі перші заперечення анатомії Галена [33]. 3.Панаскертелі-Цицишвілі серед форм лікарських засобів при хворобах сечової системи пропонував на зону сечового міхура «маджуні», «теріакі», «акрастаса», «лідімеді» (лікарські каші, коржі, розчини місцевого застосування), «гуарішні» (засоби для прийняття всередину, виготовлені на сиропі або вині), «іараджі» (одна з форм медикаментозних засобів у вигляді пігулок або мазей з цукром i медом), «матбухі» (відвари), «шаіпов» і «луакні» (їх пропонувалося лизати), «сіканкубін» (питво, виготовлене $з$ медом на оцті) та «мцнілі» (консервовані фрукти з лікарськими речовинами) [34].

На закінчення цього розділу відзначимо, що історія сучасних понять в уронефрології сягає своїм корінням в минулі століття. На думку англійського філософа Ф.Бекона (1561-1626), «наука є не що інше, як відображення дійсності». Звичайно, як казав письменник і філософ Апулей ( 125-180), «те, що ми знаємо - обмежене, а що не знаємо нескінченно». У наступних повідомленнях 2 і 3 буде представлено за нумізматичними матеріалами історію розвитку нефрології та урології епох Нового і Новітнього часу.

Конфлікт інтересів. Автори заявляють про відсутність конфлікту інтересів, при цьому автори не отримували від окремих осіб і організацій фінансової підтримки дослідження, гонорарів та інших форм винагород.

Інформація про внесок кожного співавтора.

Синяченко О.В.: збір нумізматичного матеріалу, концепція дослідження та написання статті.

Колесник М.О.: дізайн дослідження, редагування статті.

Степанова Н.M.: аналіз даних літератури за проблемою.

Ермолаєва М.В.: збір матеріалу, підготовка ілюстрацій.

\section{Лiтература (References):}

1. Kunzmann R. The Saint Eligius, his life and work and his traces in numismatics. Schweiz Arch Tierheilkd 2014;156(1):13-6. doi: 10.1024/0036$7281 / \mathrm{a} 000541$.
2. Hart GD. Ancient coins and medicine. Can Med Assoc J 1966;94(2):77-89. Available from: https://www.ncbi.nlm.nih.gov/pmc/articles/ PMC1935216/. 
3. Gemmill CL. Medical numismatic notes. 8 . Coins of Cyrene. Bull NY Acad Med 1973;49(1): 81-4. Available from: https://pubmed.ncbi.nlm.nih. gov/4565386/.

4. Allen CR. A survey of medical numismatics. Medicina in nummis. JAMA. 1981;246(20):2347-9. doi:10.1001/jama.1981.03320200033021.

5. Eknoyan $G$. The kidneys in the Bible: what happened? J Am Soc Nephrol. 2005; 16(12):3464-71. doi: 10.1681/ASN.2005091007.

6. Kottek $S S$. "The kidneys give advice": some thoughts on nephrology in the Talmud and Midrash. Korot 1994;10:44-53. Available from: https://pubmed. ncbi.nlm.nih.gov/11639673/.

7. Dvorjetski E. The history of nephrology in the Talmudic corpus. Am J Nephrol 2002;22(2-3):11929. doi: 10.1159/000063749.

8. Subba Reddy DV. Parahita Samhita. A Sanskrit medical treatise of 15 th century. A note on the book and the family offamous physicians. Bull Inst Hist Med Hyderabad 1972;2(4):199-206. Available from: https://read.qxmd.com/read/11609242/parahitasamhita-a-sanskrit-medical-treatise-of-15th-century-a-note-on-the-book-and-the-family-of-famousphysicians.

9. Chitwood A. The death of Empedocles. Am J Philol 1986;107(2):175-91. Available from: https:// pubmed.ncbi.nlm.nih.gov/16411327/.

10. Syniachenko $O V$ (red.) Revmatolohiia v oblychchiakh: numizmatychno-biohrafichnyi kataloh. Kramatorsk, Drukarskyi dim 2019:58-60. [In Ukrainian].

11. Poulakou-Rebelakou E, Marketos SG. Renal terminology from the Corpus Hippocraticum. Am J Nephrol 2002;22(2-3):146-51. doi: 10.1159/000063753.

12. Marketos $S G$. Hippocratic medicine and nephrology. Am J Nephrol 1994:14(4-6):264-9. doi: 10.1159/000168733.

13. Dardioti $V$, Angelopoulos $N$, Hadjiconstantinou $V$. Renal diseases in the Hippocratic era. Am J Nephrol 1997;17(3-4):214-6. doi: 10.1159/000169104.

14. Rose $V$. Aristotelis qui ferebantur librorum fragmenta. Lipsiae 1836;10:449-50. Available from: https:// www.worldcat.org/title/aristotelis-qui-ferebanturlibrorum-fragmenta/oclc/3739487.

15. Marandola $P$, Musitelli $S$, Jallous $H$. The Aristotelian kidney. Am J Nephrol 1994;14(4-6):302-6. doi: 10.1159/000168738.

16. Haas LF. Aretaeus of Cappodocia (130-200). J Neurol Neurosurg Psychiatry 1991;54(3):203. doi: 10.1136/jnnp.54.3.203.

17. Poulakou-Rebelakou E. Aretaeus on the kidney and urinary tract diseases. Am J Nephrol 1997;17(34):209-13. doi: 10.1159/000169103.

18. Eknoyan $G$. Rufus of Ephesus and his "Diseases of the Kidneys". Nephron.2002; 91(3):383-90. doi: $10.1159 / 000064277$.
19. Bujalkova M. Rufus of Ephesus and his contribution to the development of anatomical nomenclature. Acta Med Hist Adriat 2011;9(1):89-100. Available from: https://pubmed.ncbi.nlm.nih.gov/22047484/.

20. Bisaccia C, De Santo NG, Cirillo M, Perna A, De Santo $R$, Richet $G$. Nephrology in a medicinal dictionary of Robert James (1703-1776). J Nephrol 2011;24(17):37-50. doi: 10.5301/JN.2011.6466.

21. Mujais SK. Nephrologic beginnings: the kidney in the age of Ibn Sina (980-1037 AD). Am J Nephrol 1987;7(2):133-6. doi: 10.1159/000167449.

22. Shamsi M, Haghverdi F, Changizi Ashtiyani S. A brief review of Rhazes, Avicenna, and Jorjani's views on diagnosis of diseases through urine examination. Iran J Kidney Dis 2014;8(4):278-85. Available from: https://pubmed.ncbi.nlm.nih.gov/25001133/.

23. Angeletti LR, Cavarra B. The Perì ouron treatise of Stephanus of Athens: Byzantine uroscopy of the 6th7th centuries AD. Am J Nephrol 1997;17(3-4):22832. doi: 10.1159/000169106.

24. Pardalidis N, Kosmaoglou E, Diamantis A, Sofikitis $N$. Uroscopy in Byzantium (330-1453 AD). J Urol 2008;179(4):1271-6. doi: 10.1016/j. juro.2007.11.046.

25. Oldoni M. Uroscopy in the Salerno school of medicine. Am J Nephrol 1994;14(4-6):483-7. doi: 10.1159/000168771.

26. Diamandopoulos $A A$. Uroscopy in Byzantium. Am J Nephrol 1997;17(3-4):222-7. doi: 10.1159/000169105.

27. Eknoyan $G$. The origins of nephrology - Galen, the founding father of experimental renal physiology. Am J Nephrol 1989;9(1):66-82. doi: 10.1159/000167939.

28. Capodicasa E, Timio M. When the history of nephrology changed that of medicine. G Ital Nefrol 2004;21(3):254-8. Available from: https://pubmed. ncbi.nlm.nih.gov/15285004/.

29. $\mathrm{Li} \mathrm{HH}$. Chinese medicine. Chin Cult 1969;10:6779. Available from: https://pubmed.ncbi.nlm.nih. gov/11631801/.

30. Massry SG. Maimonides: physician and nephrologist. Am J Nephrol 1994;14(4-6):307-12. doi: 10.1159/000168739.

31. Rosner F. Nephrology and urinalysis in the writings of Moses Maimonides. Am J Kidney Dis 1994;24(2):222-7. doi: 10.1016/s02726386(12)80187-9.

32. Lebeau B. Paracelsus, physician, alchemist, philosopher. Rev Prat 2006;56(1):108-13. Available from: https://pubmed.ncbi.nlm.nih.gov/16548257/.

33. De Santo $N G$, Bisaccia $C$, De Santo LS, De Santo RM, Di Leo VA, Papalia T. et al. Berengario da Carpi. Am J Nephrol 1999;19(2):199-212. doi: 10.1159/000013452.

34. Shengeliia GM. Z.Panaskerteli-Tsitsishvili's "Medical text - Karabadini". Klin Med 1981;59(6):110-2. Available from: https://pubmed. ncbi.nlm.nih.gov/6457207/. 